Вісник Дніпропетровського університету. Біологія. Екологія. -2010. - Вип. 18, т. 2. - С. 3-8.

Visnyk of Dnipropetrovsk University. Biology. Ecology. - 2010. - Vol. 18, N 2. - P. 3-8.

УДК 612.33-02.44

О. О. Галінський, О. С. Трушенко, В. О. Галінський, О. В. Севериновська, А. І. Руденко

Дніпропетровський національний університет ім. Олеся Гончара

Дніпропетровська державна медична академія, Інститут гастроентерології НАМН України

\title{
МОТОРНА ДІЯЛЬНІСТЬ ШЛУНКА ТА ДВАНАДЦЯТИПАЛОЇ КИШКИ ЗА УМОВ БЛОКУВАННЯ NO-ЕРГІЧНОЇ СИСТЕМИ
}

Досліджено особливості ультрадних ритмів шлунка та дванадцятипалої кишки щурів при різнотривалому блокуванні $N O$-синтази та пов'язаного 3 ним порушення регуляторних механізмів. Встановлено функціональний зв'язок між змінами МЕА шлунка та дванадцятипалої кишки, а також морфологічним станом їх слизової оболонки під час порушення синтезу монооксиду нітрогену (NO). Однократне блокування $N O$-синтаз викликало підвищення показників моторного індексу шлунка та ДПК $(16,8$ та 42,4 \%, $p<0,05)$. На шосту добу дефіциту $N O$ відмічалось збільшення моторного індексу в 1,5 раза $(p<0,05)$, нав'язування ритму дванадцятипалої кишки шлунка, що супроводжувалось дуоденогастальним рефлюксом. На дванадцяту добу дефіциту $N O$ відмічалось зниження моторного індексу шлунка та ДПК порівняно з контролем, що вказує на виснаження адаптаційно-компенсаторних механізмів. Використання отриманих даних доцільне у патофізіології та у медичній практиці.

А. А. Галинский, А. С. Трушенко, В. А. Галинский, Е. В. Севериновская, А. И. Руденко

\author{
Днепропетровский национальный университет им. Олеся Гончара \\ Днепропетровская государственная медииинская академия \\ Институт гастроэнтерологии НАМН Украинь
}

\section{МОТОРНАЯ ДЕЯТЕЛЬНОСТЬ ЖЕЛУДКА И ДВЕНАДЦАТИПЕРСТНОЙ КИШКИ ПРИ БЛОКИРОВАНИИ NO-ЭРГИЧЕСКОЙ СИСТЕМЫ}

\begin{abstract}
Исследованы особенности ультрадных ритмов желудка и двенадцатиперстной кишки крыс при различной продолжительности блокирования $N O$-синтазы и связанного с этим нарушения регуляторных механизмов. Установлена функциональная связь между изменениями МЭА желудка и двенадцатиперстной кишки, а также морфологическим состоянием их слизистой оболочки при нарушении синтеза монооксида азота. Однократное блокирование $N O$-синтазы вызвало повышение показателей моторного индекса желудка и ДПК $(16,8$ и 42,4 \%). На шестые сутки дефицита NO отмечалось увеличение моторного индекса в 1,5 раза $(p<0,05)$, навязывание ритма двенадцатиперстной кишки желудка, что сопровождалось дуоденогастальным рефлюксом. На двенадцатые сутки дефицита $N O$ отмечалось снижение моторного индекса желудка и ДПК по сравнению с контролем, что указывает на истощение адаптационно-компенсаторных механизмов. Целесообразно использование полученных данных в патофизиологии и в медицинской практике.
\end{abstract}

O. O. Galyns'ky, A. S. Trushenko, V. O. Galyns'ky, O. V. Severynovs'ka, A. I. Rudenko

Oles' Honchar Dnipropetrovsk National University

Dnipropetrovsk State Medical Academy

Research Institute of Gastroenterology of Academy of Medical Sciences of Ukraine

\section{MOTOR ACTIVITY OF STOMACH AND DUODENUM WHILE BLOCKING NO-ERGIC SYSTEM}


The features of ultradian rhythms of the stomach and duodenum of rats under different time spans of blocking $\mathrm{NO}$-synthase and the associated disturbance of regulatory mechanisms have been investigated. The functional relationship between changes in the MEA of stomach and duodenum, as well as the morphological status of the mucous membrane under disturbance of the nitric monoxide synthesis have been established. Each time blocking $\mathrm{NO}$-ergic system caused an increase in motor performance index of the stomach and duodenum by $16.8 \%$ and $42.4 \%$ respectively $(p<0.05)$. On the sixth day of the $N O$ deficiency, the motor index was noted to increase 1.5 times $(p<0.05)$, the duodenum rhythm imposed on stomach. It was accompanied by the duodenogastric reflux. On the twelfth day of $N O$ deficit the reduction of the stomach and duodenum motor indices was noted, as compared with a control. It indicated exhaustion of adaptive-compensatory mechanisms. It is advisable to use of data obtained in the pathophysiology and in the medical practice.

\section{Вступ}

На сучасному етапі розвитку гастроентерологічної науки механізми координації верхніх відділів шлунково-кишкового тракту залишаються остаточно не з'ясованими. Існує неоднозначність уявлень щодо ролі $N O$-ергічної ланки у регуляції періодичної діяльності даної ділянки та змін у морфофункціональному стані органів гастродуоденальної зони за умов тривалого порушення роботи $N O$-синтази, спричиненого дефіцитом монооксиду нітрогену [2; 10].

Залежно від умов навколишнього макро- та мікросередовища $N O$ по-різному проявляє свою біологічну активність [7]. Доведено подвійну роль цього універсального ендогенного регулятора, здатного проявляти як захисну дію на слизову оболонку, так і пошкоджувальну, що залежить від концентрації цієї сполуки. 3 одного боку, оксид нітрогену має антиоксидантні властивості, регулює моторику травного тракту, шлункову секрецію, мікроциркуляцію, стимулює секрецію слизу та володіє цитопротекторною дією $[5 ; 6 ; 8] .3$ іншого боку, оксиду азоту і його метаболітам належить значна роль у патогенезі різних захворювань, у тому числі шлунково-кишкового тракту $[1 ; 4 ; 8 ; 9]$.

Для встановлення ролі $N O$ у регуляції періодичної діяльності шлунка та дванадцятипалої кишки (ДПК) нами проведено дослідження міоелектричної активності цих органів в умовах дефіциту $N O$, викликаного порушенням у роботі $N O$-ергічної системи.

Тому мета цієї статті - проаналізувати зміни міоелектричної активності шлунка, дванадцятипалої кишки в нормі та при моделюванні недостатності $N O$-синтази.

\section{Матеріал і методи досліджень}

Дослідження проводили на 40 статевозрілих лабораторних щурах-самцях масою 250-300 г, яких утримували на стандартному раціоні віварію. Усіх тварин випадковим чином поділили на чотири групи: контрольну $(n=10)$, групу тварин, яким проводили однократне блокування $N O$-синтази $(n=10)$, та тих, яким тривало проводили блокування $N O$-синтази: 6 діб $(n=10)$ та 12 діб $(n=10)$. Як блокатор $N O$-синтази тваринам уводили внутрішньочеревно $1 \%$ суспензію NG-нітро-L-аргінінметил (L-NNA) у дозі 40 мг/кг. Піддослідним тваринам блокатор вводили о 9 годині ранку упродовж 6 та 12 діб. Однократне введення L-NNA проводили під час запису електрогастроміограми та електродуоденоміограми. Реєстрацію міоелектричної активності гладеньких м’язів шлунка та дванадцятипалої кишки здійснювали за допомогою біполярних платинових голкових електродів, імплантованих під серозну оболонку цих органів. Електрод являє собою тонку неметалеву пластинку, в якій зафіксовані дві загнуті платинові голки діаметром 0,2 мм, міжелектродна відстань між якими - 0,25 мм [3]. Для реєстрації міоелектричної активності шлунка електрод фіксували в області антрального відділу, на ДПК електрод установлювали та фіксували на 5 мм каудальніше від пілоричного сфінктера. Дані реєстрували за допомогою поліграфа RM-86 Nihon Kohden. 
Для кількісного аналізу міоелектричної активності шлунка та ДПК використовували такий показник як моторний індекс - площа обмежена проінтегрованою електрогастроміограмою та електродуоденоміограмою. Цей показник відображає загальну картину моторної активності шлунка та ДПК. Кожен 3 етапів оперативного втручання здійснювали під загальною анестезією (кетамін у дозі 110 мг/кг).

Ступінь ураження слизової оболонки гастродуоденальної зони оцінювали за інтенсивністю забарвлення тканин вітальним барвником нейтрального червоного [3].

Усі вихідні дані, отримані при виконанні роботи, з метою оптимізації математичної обробки вводили у базу даних, побудовану за допомогою електронних таблиць.

Всі експерименти проведені згідно з вимогами Свропейської конвенції щодо використання лабораторних тварин у медико-фізіологічних дослідженнях. Отримані дані обробляли за допомогою стандартних методів математичної статистики з визначенням середніх величин, їх стандартних помилок та інтервалів вірогідності за $t$-критерієм Стьюдента. Відмінності, отримані методом парних порівнянь, вважали вірогідними при $p<0,05$. Математичні розрахунки та побудову графіків здійснювали з використанням пакетів програм Microsoft Excel 2007 та OriginLab OriginPro v 8.0.

\section{Результати та їх обговорення}

У контрольних тварин показники моторного індексу шлунка та ДПК коливались залежно від фаз і становили в середньому 4,66 $\pm 1,02$ та 4,55 $\pm 0,56$ мкВ/с ${ }^{2}$ відповідно. Картина міоелектричної активності в гастродуоденальній зоні мала чіткий фазний характер. Після одноразового введення L-NNA у складі хвиль спостерігалось збільшення амплітуди маскувальних коливань, на тлі яких почали проявлятись поодинокі пікові потенціали. Протягом наступних 15-20 хв відбувалось поступове збільшення кількості та амплітуди вказаних маскувальних хвиль. Через 35-45 хв після введення L-NNA у більшості випадків спостерігали електричні коливання стінки шлунка, які були схожі за складом із II-III фазою міоелектричної активності; така картина зберігалась протягом наступних 75-85 хв, тобто до кінця часу реєстрації. При цьому картина електричних коливань, подібна до III фази міоелектричної активності, спостерігалась у шлунку через 80-100 хв і тривала не більше 10-15 хв. При аналізі міоелектричної активності ДПК при блокаді нітрергічних механізмів відмічене збільшення амплітуди коливань ритму за рахунок підвищення амплітуди першого висхідного коліна повільної хвилі через 15-17 хв після введення L-NNA. У подальшому (через 20 хв) спостерігали появу III фази міоелектричної активності ДПК. Важливим $є$ те, що з 50-60-ї хв після введення L-NNA регулярна пікова активність ДПК (у вигляді спайк-потенціалів, які виникають на кожній повільній хвилі) проявлялась у вигляді відрізків по 60-120 с, які чергувались із відрізками 3 нерегулярною піковою активністю, а інколи 3 повною відсутністю спайк-потенціалів, а також відмічалось нестійке накладання на патерн міоелектричної активності дванадцятипалої кишки повільніших хвиль «шлункового походження».

Однак картина електричних коливань у шлунку, яка була подібна до III фази міоелектричної активності та спостерігалась через 80-100 хв, не супроводжувалась відповідними змінами міоелектричної активності ДПК. Остання у цей час «відповідала» фазою спокою, на тлі якої виникали неперіодичні групи пікових коливань або ж замість них - поодинокі спайк-потенціали, що зумовлювало картину переходу I фази міоелектричної активності до II фази (або початку II фази) міоелектричної активності ДПК, яка тривала до кінця реєстрації. Кількісно порівняти міоелектричну активність органів гастродуоденальної зони складно, тому що показники амплітудночастотної характеристики міоелектричної активності цих органів спотворені тривалим 
блокуванням NO-синтази. Вирішення цієї проблеми можливе тільки у разі використання показника моторного індексу. Нами встановлено, що моторний індекс змінювався після введення L-NNA (табл. 1).

Таблиия 1

Показники моторного індексу після різнотривалого введення L-NNA

\begin{tabular}{|l|c|c|}
\hline \multicolumn{1}{|c|}{ Варіант досліду } & Моторний індекс шлунка, мкВ/с ${ }^{2}$ & Моторний індекс ДПК, мкВ/с ${ }^{2}$ \\
\hline Інтактна група & $4,65 \pm 0,23$ & $4,55 \pm 0,14$ \\
\hline Однократне введення блокатора & $5,44 \pm 0,19^{*}$ & $6,49 \pm 0,21^{*}$ \\
\hline Шість діб блокування & $6,20 \pm 1,10^{*}$ & $6,00 \pm 0,58^{*}$ \\
\hline Дванадцять діб блокування & $3,90 \pm 1,20^{*}$ & $2,60 \pm 1,16^{*}$ \\
\hline
\end{tabular}

Примітка: ${ }^{*}-p<0,05$.

За амплітудно-частотною характеристикою міоелектричної активності та показниками моторного індексу гастродуоденальної зони встановлено, що однократне блокування NO-синтази не вносить суттєвих якісних змін у картину періодичної діяльності цих органів. Збільшення активності відмічалося незалежно від того, протягом якої фази був уведений блокатор.

Після шестидобового порушення $N O$-ергічної ланки регуляції періодичної діяльності шлунка та ДПК фаза міоелектричної активності шлунка була подібною до переходу між II та III фазами, переважала пізня II та рання III фази, I фаза була не визначена протягом запису. При тривалому порушенні роботи $N O$-ергічної ланки регуляції періодичної активності гастродуоденальної зони значення моторного індексу суттєво відрізнялися від значень контрольних тварин і ці зміни залежали від тривалості блокування $N O$-синтази. Одноразове блокування $N O$-синтази, незалежно від фази періодичної діяльності шлунка та ДПК, викликало підвищення показників моторного індексу на 16,8 та $42,4 \%$ ( $p<0,05)$ відповідно. На шосту добу дефіциту $N O$ відмічалось збільшення моторного індексу в 1,5 раза $(p<0,05)$, електрогастроміограмма відрізняється нестабільністю періоду ритму, збільшенням показників амплітуди та збільшенням періоду коливання порівняно 3 інтактними показниками. Фази міоелектричної активності шлунка можливо ідентифікувати тільки на основі моторного індексу. Відбувається нав'язування ритму дванадцятипалої кишки шлунка, що супроводжується дуоденогастальним рефлюксом. На 12-ту добу дефіциту $N O$ відмічалось зниження моторного індексу шлунка на $27 \%(p<0,05)$, ДПК - на 59 \% $(p<0,05)$.

Вплив тривалого блокування $N O$-синтази викликав зміни тривалості фаз міоелетричної активності (табл. 2), чого не спостерігалось при одноразовому застосуванні L-NNA.

Таблиия 2

Зміни тривалості фаз міоелектричної активності шлунка та ДПК протягом двох годин запису

\begin{tabular}{|l|c|c|c|c|}
\hline \multirow{2}{*}{ Варіант досліду } & \multicolumn{2}{|c|}{ Тривалість фаз шлунка, хв } & \multicolumn{2}{c|}{ Тривалість фаз ДПК, хв } \\
\cline { 2 - 5 } & I фаза & II та III фази & I фаза & II та III фази \\
\hline Інтактна група & $70-90$ & $30-50$ & $70-80$ & $30-40$ \\
\hline Шість діб блокування & $40-50$ & $70-80$ & $50-60$ & $60-70$ \\
\hline Дванадцять діб блокування & $20-30$ & $80-100$ & не спостерігалась & 120 \\
\hline
\end{tabular}

Дані досліджень вказують на збільшення тривалості активних фаз після тривалого блокування $N O$-синтази. При тривалому порушенні $N O$-ергічної ланки регуляторних 
механізмів періодичної діяльності шлунка та ДПК спостерігалась тенденція до збільшення тривалості II-III та зникнення I фази.

Морфологічних змін у тканинах слизової оболонки шлунка щурів після одноразового та шестидобового уведення L-NNA не виявлено. Перевірка морфологічного стану слизової оболонки шлунка після дванадцятидобового блокування $N O$-синтази підтвердила наявність заблокованих $N O$-синтаз. Макро- та мікроскопічний аналіз морфологічного стану слизової оболонки шлунка в цій серії експериментів виявив наявність гострих виразок (від двох до чотирьох), розташованих переважно в тілі шлунка (досягають м'язової пластинки з некрозом до середньої третини). У зоні виразки у власній пластинці слизової оболонки шлунка та у зоні шлункових залоз спостерігалась щільна нейтрофільно-еозинофільна клітинна інфільтрація з розташуванням у вигляді вузьких тяжів на обмеженій ділянці у м'язову оболонку. При цьому у віддаленій від виразки ділянці біоптату відмічено зменшення вмісту парієтальних і головних клітин із заміною ї на слизотвірні, які містили значну кількість кислих мукополісахаридів. Макро- та мікроморфологічні дослідження слизової оболонки шлунка показують наявність виразкових ушкоджень після дванадцятидобового блокування $N O$-синтаз, етіологія та патогенез яких потребують подальшого дослідження з метою встановлення факторів впливу, які викликають ці порушення.

Важливе подальше дослідження особливостей перебудови місцевих нейрогуморальних механізмів регуляції при тривалій стимуляції або блокаді нітрергічних механізмів, що дозволить точніше зрозуміти взаємодію гуморальних і нервових механізмів регуляції функцій шлунково-кишкового тракту при порушенні періодичної активності травної системи. Крім того, виявлення шляхів впливу $N O$-ергічної ланки на вказані механізми дозволить увдосконалити методичні підходи до діагностики захворювань шлунково-кишкового тракту.

\section{Висновки}

Однократне блокування $N O$-синтаз, незалежно від фази періодичної діяльності, викликало підвищення показників моторного індексу шлунка та ДПК 16,8 та 42,4 \% $(p<0,05)$. На шосту добу дефіциту $N O$ відмічалось збільшення моторного індексу в 1,5 раза $(p<0,05)$, нав'язування ритму дванадцятипалої кишки шлунка, що супроводжувалось дуоденогастальним рефлюксом. На дванадцяту добу дефіциту $N O$ відмічалось зниження моторного індексу шлунка та ДПК порівняно з контролем, що вказує на виснаження адаптаційно-компенсаторних механізмів. При тривалому порушенні $N O$-ергічної ланки регуляторних механізмів періодичної діяльності гастродуоденальної зони спостерігалась тенденція до збільшення тривалості II-III та зникнення I фази. Тривале блокування нітроергічних механізмів регуляції зумовлювало утворення множинних ерозій і гострих виразок округлої та овальної, рідше полігональної форм. Тривалий дифіцит $N O$ призводить до дисбалансу періодичної діяльності шлунка та ДПК, порушення міоелектричної активності в напрямку декомпенсаційних проявів.

\section{Бібліографічні посилання}

1. Абасова А. С. Динамика содержания оксида азота в желудочном соке у больных с кислотозависимыми заболеваниями желудка и двенадцатиперстной кишки: Автореф. дисс. ... канд. мед. наук. - Махачкала, 2009. - 26 с.

2. Ивашкин В. Т. Клиническое значение оксида азота и белков теплового шока / В. Т. Ивашкин, О. М. Драпкина. - М. : Гэотар-Медиа, 2001. - 84 с. 
3. Трушенко О. С. Міоелектрична активність шлунка та дванадцятипалої кишки при ушкодженні гастродуоденальної ділянки / О. С. Трушенко, О. Б. Мурзін, А. І. Руденко // Фізіологічний журнал. - 2006. - Т. 52, № 2. - С. 169.

4. Щербак В. А. Содержание метаболитов оксида азота в крови и желудочном соке у детей с хроническим дуоденитом // Вопросы современной педиатриии. - 2007. - Т. 6, № 6. - С. 54-57.

5. Gastroprotective and blood pressure lowering effects of dietrary nitrate are abolished by anmuthwash / J. Petersson, M. Carlstrom, O. Schreiber et al. // Biol. Med. - 2009. - Vol. 46, N 8. P. 1068-1075.

6. Konturek J. W. Endogenous nitric oxide in the regulation of gastric secretory and motor activity in humans / J. W. Konturek, H. Fischer, P. M. Gromotka // Aliment Pharmacol Ther. - 1999. - Vol. 13. P. 1683-1691.

7. Nitric oxide is involved in heat-induced HSP70 accumulation / L. Y. Malyshev, E. B. Manukhina, V. D. Mikoyan et al. // FEBS Lett. - 1995. - Vol. 370. - P. 159-162.

8. Nitrite in saliva increases gastric mucosal blood flow and mucus thickness / H. Björne, J. Petersson, M. Phillipson et al. // J. Clin. Invest. - 2004. - Vol. 113, N 1. - P. 106-114.

9. Ozmeric N. Advnces in peroriodontal disease markers // Clin. Chim. Acta. - 2004. - Vol. 343, N 1-2. - P. 50.

10. Sivarao D. V. Pyloric sphincter dysfunction in nNOS-/- and W/Wv mutant mice: Animal models of gastroparesis and duodenogastric reflux / D. V. Sivarao, H. Mashimo, R. K. Goyal // Gastroenterology. - 2008. - Vol. 135, N 4. - P. 1258-1266.

Надійшла до редколегї 14.10.2010 